\title{
Komunikasi Organisasi Event Project Team dan Account Executive pada Event Organizer Twisbless
}

\author{
Innaka Dwi Hasanti ${ }^{*}$ \\ ${ }^{1}$ STIKOM The London School of Public Relations Jakarta \\ Jl. K.H Mas Mansyur, Kav. 35, Jakarta 10220 - Indonesia \\ *Email korespondensi: innakadwi@gmail.com
}

\begin{abstract}
Abstrak
Berhasilnya sebuah event membutuhkan komunikasi yang baik di antara tim project dan Account Executive yang terlibat dalam event tersebut. Project Team dalam sebuah event organizer yang bertugas untuk mengeksekusi acara di lapangan sedangkan tugas dari account executive adalah menjaga komunikasi antara tim internal perusahaan dengan kliennya serta menampung segala hal yang dibutuhkan dan diinginkan klien. Tujuan penelitian ini adalah untuk mengetahui arus komunikasi organisasi yang diterapkan oleh tim project dan account executive di Event Organizer Twisbless serta mengetahui hambatan komunikasi organisasi yang ada di Twisbless. Teori yang digunakan adalah teori komunikasi organisasi. Pendekatan penelitian yang digunakan adalah kualitatif. Subjek dalam penelitian ini adalah karyawan Twisbless yang berperan sebagai tim project dan account executive. Teknik pengumpulan data yang digunakan adalah wawancara dan observasi terhadap empat orang narasumber yang bekerja di Twisbless. Temuan penelitian: komunikasi organisasi yang diterapkan oleh tim project dan account executive di Twisbless adalah komunikasi internal dan eksternal dimana komunikasi internal terbagi menjadi empat arus yaitu, komunikasi arus atas, komunikasi arus bawah, komunikasi diagonal, dan komunikasi horizontal. Lalu terdapat berbagai macam hambatan yang ada dalam proses komunikasi organisasi yaitu gangguan teknis, gangguan semantik, rintangan fisik, gangguan psikologi dan rintangan kerangka berpikir sehingga menimbulkan kendala dan dampak yang berpengaruh terhadap kelancaran suatu event.
\end{abstract}

Kata kunci : Account Executive, Event, Komunikasi Organisasi, Project Team

\section{PENDAHULUAN}

Di Indonesia, bisnis jasa pelaksana acara dan profesi sebagai event organizer (EO) atau tepatnya event manager adalah jenis pekerjaan yang juga tergolong baru. Tumbuhnya bisnis EO di Indonesia beriringan dengan semakin maraknya dunia showbiz dan bangkitnya perekonomian Indonesia setelah dilanda krisis moneter internasional pada pertengahan tahun 1997 (Natoradjo, 2011).

Saat ini, EO banyak bergerak di beberapa bidang seperti pertunjukan musik, pameran produk (mobil, komputer, handycraft), peluncuran produk, sampai dengan wedding party. Sesungguhnya praktek EO di Indonesia sudah ada sejak tahun 1990an dimana dimulai dari pesta-pesta adat yang panitia pestanya tersebut mulai membagi tugas masing-masing untuk mendukung suksesnya suatu acara. Pembagian tugas ini juga ada pada acara kematian dan pesta adat lainnya (Syaikhon, 2013).

Sejak berkembangnya penyelenggaraan event sejenis eksibisi atau expo oleh perusahaan untuk memperkenalkan produknya, maka mulai banyak perusahaan yang memiliki divisi khusus untuk menangani kegiatan event perusahaan, tetapi sejak terjadinya krisis ekonomi pada akhir tahun 1990 sampai awal tahun 2000, divisi ini hanya menjalankan fungsinya pada saat tertentu saja sehingga perusahaan mulai menutup divisi tersebut dan mulai bekerjasama dengan EO dari luar perusahaan untuk menjalankan event perusahaan tersebut (Noor, 2017).

Tentu saja peluang untuk bisnis EO ini cukup cerah melihat kegiatan orang-orang zaman sekarang yang ingin serba instan dan tidak mau repot dengan urusan-urusan yang rumit. Beberapa event besar 
masih menggunakan EO dari luar daerah, tentu saja ini merupakan peluang yang harus kita bidik sebagai penghuni daerah (Syaikhon, 2013).

Pada dasarnya EO bertugas untuk membantu kliennya agar dapat menyelenggarakan acara yang diinginkan. Tugas EO mengorganisir segala keperluan event mulai dari tahap persiapan (pra produksi), event berjalan dengan baik dan lancar (produksi) serta pelaporan dan evaluasi (pasca produksi) (Hafidz, 2017). Agar event berjalan dengan baik dan sukses, apa pun jenisnya, event berlangsung melalui sebuah proses yang terdiri dari beberapa tahap guna memastikan keberhasilannya. Goldblatt (2002, dalam Natoradjo, 2011) dan Silvers (2004, dalam Natoradjo, 2011) mengungkapkan bahwa pada prinsipnya proses itu terdiri dari lima tahap, yaitu melakukan penelitian, membuat desain event, merencanakan (planning), mengkoordinasikan pelaksanaan event, melakukan penilaian atau evaluasi.

Jika melihat dari struktur organisasi sebuah EO, maka akan ditemukan berbagai posisi dan jabatan yang tentunya disesuaikan dengan acara yang akan diselenggarakan. Struktur organisasi event biasanya terdiri dari lima divisi utama, yaitu operasional pelayanan pengunjung, operasional pelayanan pendukung, marketing, administrasi dan keuangan (Noor, 2017).

Lima divisi utama dalam struktur organisasi yang ada di PT. Talenta Wirama Berkat yaitu tim project, tim produksi, account executive, tim kreatif dan tim finance dan support. Tugas Project Team adalah mengatur flow acara, mengatur bagian teknis event, mengkoordinir semua pihak yang terlibat dalam event tersebut, mematangkan konsep bersama creative team dan account executive, dan menjalankan atau mengimplementasikan konsep yang sudah matang dan sudah disetujui oleh pihak klien dan EO itu sendiri, maka dari itu, Project Team harus memiliki pola komunikasi yang baik sehingga saat menjalankan sebuah event dapat berjalan dengan lancar dan guna mengurangi resiko terjadinya kesalahan teknis saat event berlangsung.

Sedangkan Account Executive bertugas untuk bertemu dan berhubungan langsung dengan klien untuk membahas event seperti apa yang klien inginkan, menyampaikan beberapa pilihan konsep dan ide dari creative team dan project team, dan dealing dengan klien. Posisi Account Executive adalah jembatan antara klien dengan Project Team dan Creative Team.

Setiap adanya project event yang baru, Account Executive bertugas untuk bertemu client untuk membahas konsep event yang client inginkan. Setelah semua materi konsep dari klien didapatkan, Account Executive langsung menyampaikan konsep tersebut kepada Project Team (Project Manager \& Project Officer) untuk membahas mengenai kelayakan konsep tersebut untuk diterapkan dan melakukan pembahasan revisi konsep apabila konsep dari klien dianggap kurang bagus atau kurang layak. Pembahasan konsep ini dilakukan melalui meeting internal yang juga melibatkan creative team dan production team untuk membahas mengenai desain materi promosi, desain produksi seperti booth dan ornamen event, dan konsep juga unik sebagai masukan tambahan.

Sebagai salah satu contoh kegagalan yang pernah dialami PT Talenta Wirama Berkat adalah saat event Sharp berlangsung dimana event tersebut adalah event yang berupa charity untuk menyumbangkan baju-baju layak pakai. Kegagalan yang dialami oleh PT Talenta Wirama Berkat berupa tidak tercapainya target yang diinginkan karena konsep yang digunakan pada event tersebut masih bersifat trial dan jadwal produksi yang tidak sesuai timeline.

Meningkatnya persaingan industri bisnis manajemen acara yang semakin hari semakin ketat membuat setiap event organizer bersaing dalam merancang dan menghasilkan sebuah acara yang menarik, kreatif, dan bernilai tinggi. Sangat penting bagi sebuah event organizer untuk memiliki manajemen komunikasi organisasi yang baik dan efektif terhadap seluruh divisi internal untuk 

menghasilkan acara yang sukses dan bernilai tinggi serta dapat membuat klien mendapat feedback positif dari para audience acara dan puas dengan pelayanan event organizer tersebut. Permasalahan yang sedang terjadi di PT Talenta Wirama Berkat adalah sering terjadinya miss-communication di antara Project Team dan Account Executive yang menyebabkan jadwal produksi tidak sesuai dengan timeline yang telah dibuat sehingga timeline acara menjadi terulur waktunya, yang seharusnya dapat selesai di pagi hari tetapi menjadi selesai di siang hari. Oleh karena itu, penulis ingin meneliti pola komunikasi organisasi yang diterapkan antara Project Team dan Account Executive.

Sebagai salah satu event organizer yang bergerak aktif di Jakarta, PT. Talenta Wirama Berkat atau Twisbless merupakan salah satu event organizer yang sudah memiliki klien tetap di Jakarta. Didirikan pada bulan September 2009, Twisbless (PT. Talenta Wirama Berkat) mengkhususkan diri dalam kegiatan pemasaran \& manajemen acara seperti; Brand Activation, Peluncuran Produk, Pameran, Seminar, Konferensi, dan Company Gathering. Pendekatan pemasaran Twisbless dimulai dengan memahami kebutuhan pelanggan yang menginginkan customer value yang berkelanjutan. Lebih dari itu, Twisbless terus menghadirkan gagasan dan konsep Segar - Kreatif - Inovatif di setiap aspek aktivasi pemasaran \& manajemen acara yang disampaikan untuk klien. Didedikasikan untuk mengupayakan keunggulan pelanggan, Twisbless telah mengembangkan bisnis ini menjadi "ONE STOP INTEGRATED MARKETING SERVICES" untuk mengakomodasi pertumbuhan dan permintaan pelanggan. Sebagai Talenta Group, Twisbless juga menyediakan Creative Design \& Booth Production, Man Power Management \& Community Organizer. Twisbless dengan bangga berkomitmen untuk memberikan layanan yang berharga kepada klien melalui internal dan nilai kerja mereka yang menekankan pada kreativitas, semangat, integritas, dan kepercayaan (Twisbless, n.d.).

Sebagai salah satu event organizer di Jakarta, PT.Talenta Wirama Berkat memiliki misi untuk terus mengembangkan pola komunikasi organisasi yang diterapkan di dalam perusahaan tersebut agar bisa terus bertahan ataupun berkembang untuk menjadi event organizer terbaik yang menghasilkan sebuah acara yang menarik, kreatif, dan bernilai tinggi di Jakarta.

Fenomena kasus kegagalan pada event Sharp dan seringnya terjadi miss-communication antara event project team dan account executive di PT. Talenta Wirama Berkat merupakan masalah yang layak untuk diteliti guna mencari tahu solusi yang tepat untuk dapat diterapkan oleh PT. Talenta Wirama Berkat dalam proses komunikasi orgasnisasinya agar PT. Talenta Wirama Berkat dapat bertahan dalam persaingan bahkan lebih unggul dalam dunia bisnis event organizer. Hal tersebut menjadi daya tarik penelitian ini hingga lahirlah pertanyaan penelitian : "Bagaimanakah arus komunikasi organisasi yang diterapkan oleh event organizer PT. Talenta Wirama Berkat?”.

\section{KAJIAN TEORI}

\section{Komunikasi Organisasi}

Menurut Liliweri (2014), komunikasi organisasi adalah studi tentang bagaimana orang-orang yang bekerja di dalam organisasi berkomunikasi dalam konteks organisasi, serta interaksi dan pengaruh antara struktur organisasi dalam perorganisasian (p. 365).

Pace \& Faules (2013) menambahkan bahwa komunikasi organisasi merupakan pertunjukkan dan penafsiran pesan diantara unit komunikasi (orang dalam jabatan) yang merupakan bagian dari suatu organisasi tertentu. Dalam suatu organisasi terdiri dari unit-unit komunikasi dalam hubungan hierarkis antara yang satu dengan yang lainnya dan berfungsi dalam lingkungan” (p.31). 


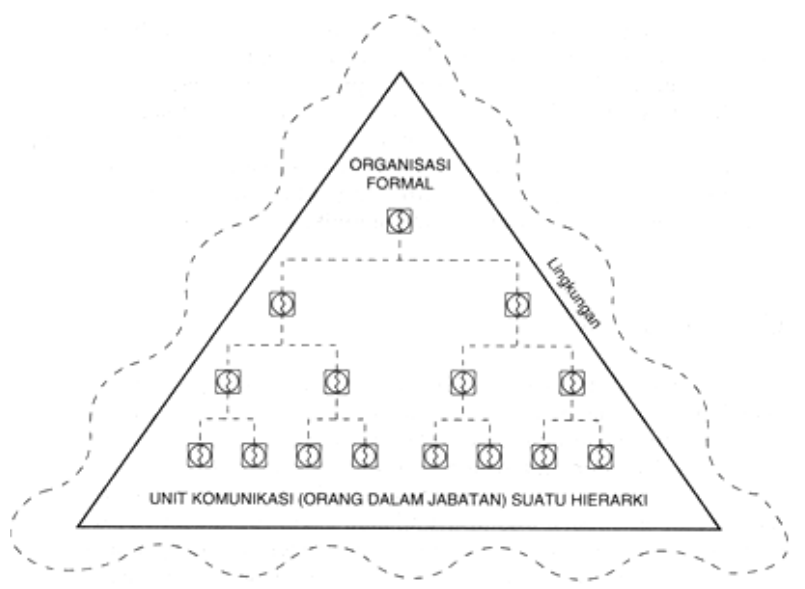

Gambar 1.Sistem Komunikasi Organisasi

\section{Dimensi Komunikasi Organisasi}

Berdasarkan ruang lingkupnya, Lawrence D. Brennan (dalam Effendy, 2011) mengatakan bahwa komunikasi organisasi dibedakan atas dua, yaitu komunikasi internal dan eksternal. Komunikasi internal adalah pertukaran gagasan di antara para administrator dan karyawan dalam suatu perusahaan atau jawatan yang menyebabkan terwujudnya perusahaan atau jawatan lengkap dengan strukturnya yang khas (organisasi) dan pertukaran gagasan secara horizontal dan vertikal di dalam perusahaan atau jawatan yang menyebabkan pekerjaan berlangsung (operasi dan manajemen). Sedangkan komunikasi eksternal ialah komunikasi antara pimpinan organisasi dengan khalayak di luar organisasi. Komunikasi eksternal terdiri atas dua jalur secara timbal balik, yakni komunikasi dari organisasi kepada khalayak dan dari khalayak kepada organisasi.

\section{Arus Komunikasi Organisasi}

Arus atau aliran informasi dalam suatu organisasi adalah suatu proses dinamik. Dalam proses inilah pesan-pesan secara tetap dan berkesinambungan diciptakan, ditampilkan, dan diinterpretasikan. Proses ini berlangsung terus dan berubah secara konstan. Artinya, komunikasi organisasi bukanlah sesuatu yang terjadi kemudian berhenti. Komunikasi terjadi sepanjang waktu

Arus komunikasi organisasi terbagi menjadi empat, yaitu :

1. Komunikasi ke Bawah (Downward Communication)

Informasi mengalir dari jabatan berotoritas lebih tinggi kepada mereka yang berotoritas lebih rendah.

2. Komunikasi ke Atas (Upward Communication)

Informasi mengalir dari tingkat yang lebih rendah (bawahan) ke tingkat yang lebih tinggi (penyelia).

3. Komunikasi Horizontal

Terdiri dari penyampaian informasi di antara rekan-rekan sejawat dalam unit kerja yang sama. Unit kerja meliputi individu-individu yang ditempatkan pada tingkat otoritas yang sama dalam organisasi dan mempunyai atasan yang sama.

4. Komunikasi Lintas Saluran

Penyampaian informasi yang melewati batas-batas fungsional dengan individu yang tidak menduduki posisi atasan maupun bawahan mereka. (Pace \& Faules, 2013). 


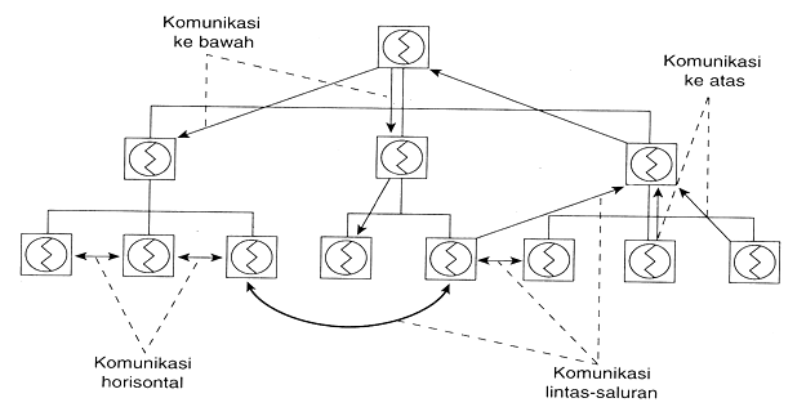

Gambar 2. Empat Arah Komunikasi Organisasi

\section{Hambatan Komunikasi Organisasi}

Dalam sebuah organisasi, komunikasi yang dilakukan tidak selalu berjalan mulus. Terkadang ada hal yang membuat komunikasi antara suatu organisasi terganggu dan terhambat sehingga menghasilkan suatu informasi yang salah atau menghasilkan misunderstanding diantara orang-orang di dalam organisasi tersebut. Menurut Cangara (2016, pp.167-170), ada beberapa faktor yang menyebabkan komunikasi organisasi terhambat, antara lain :

a. Gangguan teknis, terjadi jika kesalahan suatu alat yang digunakan dalam berkomunikasi mengalami gangguan, sehingga informasi yang ditransformasikan sulit untuk diterima atau dipahami oleh komunikan.

b. Gangguan semantik, komunikasi yang disebabkan kesalahan pada bahasa yang digunakan.

c. Gangguan psikologi, terjadi karena adanya gangguan yang disebabkan oleh persoalan-persoalan dalam diri individu.

d. Rintangan fisik atau organik, disebabkan karena kondisi geografis misalnya jarak sosial di antara peserta komunikan, seperti senior dan junior.

e. Rintangan kerangka berfikir, disebabkan adanya perbedaan persepsi antara komunikator dan komunikan terhadap khalayak yang digunakan dalam berkomunikasi, ini disebabkan latar belakang pengalaman dan pendidikan yang berbeda.

f. Rintangan budaya, disebabkan adanya perbedaan norma, kebiasaan dan nilai yang dianut oleh pihak-pihak yang terlibat dalam komunikasi.

\section{Kerangka Konsep}

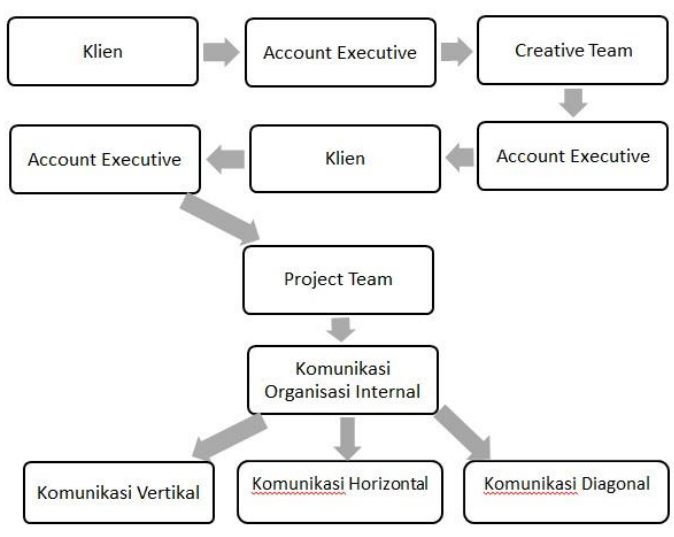

Gambar 3. Kerangka Konsep 


\section{METODE}

Penelitian ini menggunakan jenis penelitian kualitatif. Penelitian dilakukan pada informan selaku karyawan Twisbless yang menjabat sebagai Head of Project Division, Project Manager, Project Officer dan Account Executive dari bulan Desember 2017 sampai April 2018. Teknik pengambilan data yang digunakan adalah observasi dan wawancara. Dalam penelitian ini, teknik analisis hasil wawancara dengan teknik analisis dan struktus analisis strategi umum, struktur analisis linear dan struktur komparatif. Peneliti menggunakan dua macam cara triangulasi data yaitu triangulasi sumber dan triangulasi metode untuk mengecek ulang derajat kepercayaan dengan melakukan wawancara dengan seorang event organizer expert dan empat orang karyawan PT. Talenta Wirama Berkat dengan fokus penelitian sebagai berikut :

Tabel 1. Fokus Penelitian

\begin{tabular}{ccc}
\hline \multicolumn{2}{c}{ Objek Penelitian : Komunikasi Organisasi Internal antara Project Team dan } \\
Eccount Executive
\end{tabular}

\section{HASIL DAN PEMBAHASAN}

Dari hasil penelitian, proses komunikasi yang dilakukan oleh tim event organizer dengan klien sejak awal pitching hingga terselenggaranya event tersebut dapat digambarkan sebagai berikut : 


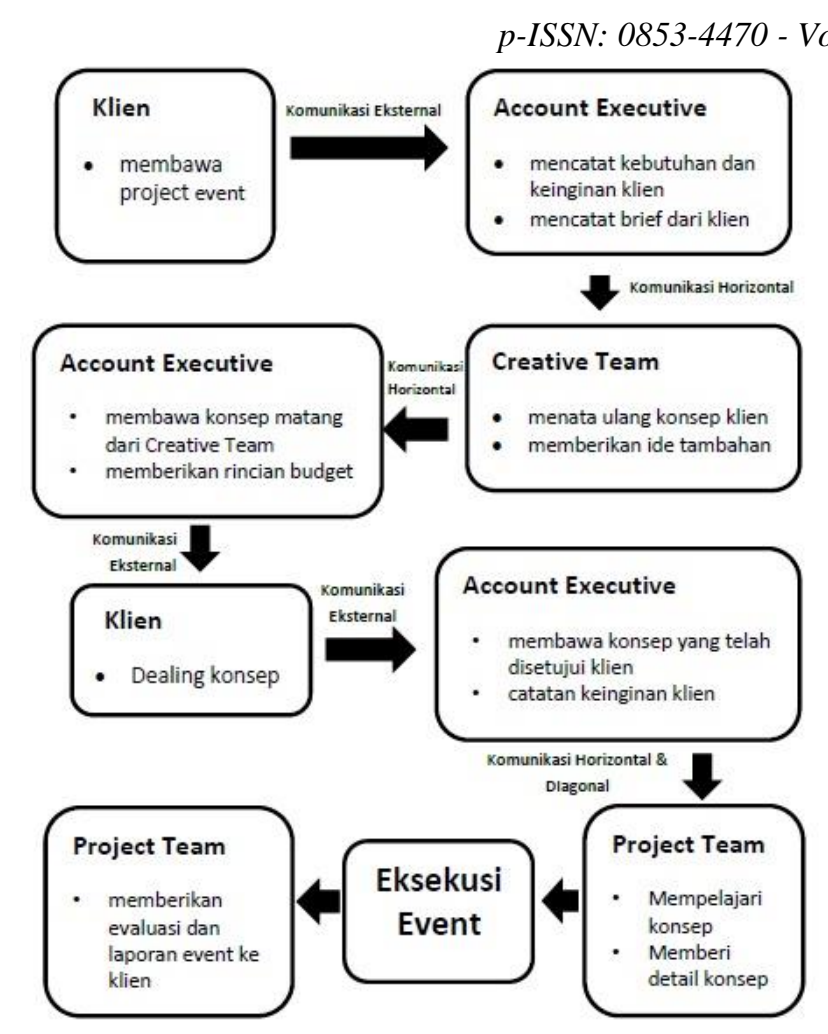

Gambar 4. Proses Komunikasi Saat Pengadaan Event

1. Pertemuan klien dengan EO

Langkah awal proses mengadakan event dimulai dari klien yang akan mengundang tim event organizer yang meliputi account executive dan tim kreatif untuk di briefing mengenai kebutuhan event dan gambaran konsep yang diinginkan. Kepada account executive, klien memberikan rincian budget yang akan mereka keluarkan untuk event yang akan dijalankan. Komunikasi yang dilakukan oleh klien dengan account executive merupakan komunikasi eksternal.

2. Briefing Konsep

Setelah itu, account executive mengadakan briefing internal dengan tim kreatif mengenai konsep yang nantinya akan dikembangkan semenarik mungkin oleh tim kreatif dengan tujuan agar perusahaannya menang pitching project event tersebut. Komunikasi yang dilakukan antara account executive dengan tim kreatif merupakan komunikasi horizontal. Setelah konsep tersebut matang oleh tim kreatif, account executive akan mengecek terlebih dahulu apakah konsep tersebut dapat diimplementasikan dengan batasan budget yang klien inginkan.

3. Pengajuan Proposal ke Klien

Jika konsep sudah cocok dengan budget yang dihitung account executive, account executive kemudian akan memberikan konsep tersebut yang sudah disusun menjadi proposal ke klien.

4. Persetujuan dan Perjanjian Proposal

Jika konsep yang dibuat oleh tim kreatif telah disetujui klien, account executive akan melakukan dealing dengan klien dan membuat perjanjian mengenai pembagian tugas untuk menjalankan event tersebut

5. Persiapan Materi

Setelah klien menyetujui konsep, account executive langsung memberikan brief kepada tim project mengenai konsep tersebut dimana dalam tim project terdapat head of project division, project manager dan project officer. Konsep tersebut kemudian akan dijabarkan lagi secara detail 
p-ISSN: 0853-4470 - Vol. 02, No. 01 (2019), pp. 61-73 oleh tim project untuk disusun menjadi manual book serta checklist yang akan menjadi acuan project officer dalam mengeksekusi event sesuai dengan flow yang telah disusun. Komunikasi horizontal yang terjadi pada proses ini adalah komunikasi yang dilakukan antara account executive dan project manager, sedangkan komunikasi diagonal terjadi pada komunikasi yang dilakukan antara account executive dengan head of project division dan project officer.

6. Eksekusi

Dalam proses ini, yang betugas di lapangan hanyalah tim project. Di lapangan, tim project akan mengurus dan melengkapi semua kebutuhan event sesuai dengan checklist dan timeline yang telah dibuat sebelumnya. Dalam proses ini, komunikasi vertikal terjadi pada saat head of project division memberikan arahan di lapangan kepada project manager maupun project officer.

7. Evaluasi

Setelah event selesai, tim project akan membuat evaluasi serta report tentang event yang telah diselenggarakan yang nanti akan dibawakan ke klien saat meeting evaluasi. Proses komunikasi yang terjadi saat tim project memberikan evaluasi dan report event merupakan komunikasi eksternal.

Hasil penelitian ini memperkuat pernyataan Suseno (2005) bahwa proses yang harus dilalui dalam mengadakan event antara lain adalah pertemuan antara klien dan EO, pengajuan proposal kepada klien, persetujuan dan perjanjian proposal dan persiapan materi.

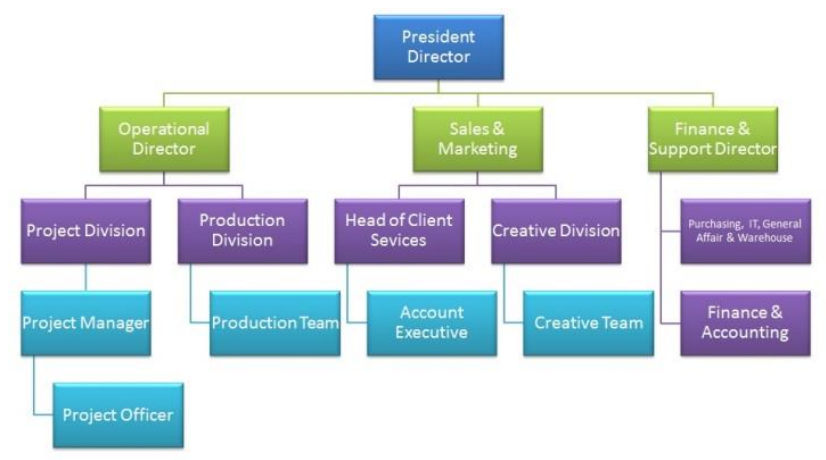

Gambar 5. Struktur Organisasi Twisbless

Tabel 2. Profil Narasumber

\begin{tabular}{ccc}
\hline Nama & $\begin{array}{c}\text { Lama } \\
\text { Profesi }\end{array}$ & Jabatan Saat Ini \\
\hline $\begin{array}{c}\text { Ressa } \\
\text { (RA) }\end{array}$ & 4 tahun & $\begin{array}{c}\text { Senior Account } \\
\text { Executive }\end{array}$ \\
\hline $\begin{array}{c}\text { Garry } \\
\text { (GT) }\end{array}$ & 6 tahun & $\begin{array}{c}\text { Head of Project } \\
\text { Division }\end{array}$ \\
\hline Ali (AA) & 6 tahun & Project Manager \\
\hline Adi (AS) & 8 tahun & $\begin{array}{c}\text { Senior Project } \\
\text { Officer }\end{array}$ \\
\hline $\begin{array}{c}\text { Shelly } \\
\text { (SR) }\end{array}$ & 10 tahun & $\begin{array}{c}\text { Event Organizer } \\
\text { Expert (Direktur } \\
\text { Global EO) }\end{array}$ \\
\hline
\end{tabular}




\section{Vertikal (Atas)}

- Project Manager (AA) ke Head of Project Division (GT)

Membahas mengenai plotting tim yaitu pembagian tim untuk event-event yang akan dijalankan dan membahas mengenai kerjasama dengan EO partner untuk event yang diselenggarakan di luar kota Jakarta. Komunikasi arus atas yang dilakukan terjadi hampir setiap hari melalui telepon.

- Project Officer (AS) ke Head of Project Division (GT) dan Project Manager (AA)

Membahas mengenai idealisme terkait pekerjaan. Komunikasi arus atas yang dilakukan sering terjadi saat adanya event. Komunikasi dilakukan secara langsung melalui forum ataupun meeting dan secara tidak langsung melalui media komunikasi seperti whatsapp group, email, ataupun telepon.

\section{Vertikal (Bawah)}

\section{- Head of Project Division (GT) ke Project Manager (AA) dan Project Officer (AS)}

Membahas tentang kebutuhan man power yaitu kru tambahan (freelancer) untuk membantu melancarkan event yang sedang berjalan, lalu ia juga membahas tentang target KPI project event, koodirnasi mengenai budget yang diturunkan account executive guna sebagai cross-check agar margin perusahaan tetap stabil dan koordinasi dengan vendor-vendor yang diajak bekerjasama untuk event-event besar yang membutuhkan lebih banyak equipment. Komunikasi arus ke bawah yang dilakukan terjadi secara langsung melalui meeting internal minimal seminggu sekali. Jika event yang berlangsung banyak, komunikasi dapat terjadi dua kali dalam seminggu, sedangkan komunikasi yang dilakukan melalui media komunikasi seperti whatsapp group terjadi setiap hari.

\section{- Project Manager (AA) ke Project Officer (AS)}

Membahas mengenai masalah flow event dan update mengenai event yang sedang berjalan. Komunikasi arus bawah yang dilakukan secara langsung atau tatap muka jarang terjadi, yaitu hanya saat weekly meeting yang dilakukan seminggu sekali, tetapi komunikasi yang dilakukan melalui media komunikasi dengan bawahannya sering terjadi melalui telepon.

\section{Horizontal}

\section{- Project Manager (AA) ke Account Executive (RA)}

Membahas mengenai perubahan tim koordinasi dari klien. Komunikasi arus horizontal sering terjadi hampir setiap hari melalui tatap langsung pada saat meeting maupun melalui media komunikasi yaitu telepon.

\section{- Account Executive (RA) ke Project Manager (AA)}

Membahas mengenai masalah pemahaman project yang sedang ingin dijalankan. Komunikasi arus horizontal sering terjadi, yaitu sebanyak tiga kali dalam seminggu melalui tatap langsung pada saat meeting di kantor maupun saat meeting di luar kantor, sedangkan komunikasi melalui media komunikasi seperti whatsapp dan email terjadi setiap hari.

\section{Diagonal}

\section{- Head of Project Division (GT) ke Account Executive (RA)}

Membahas mengenai budget, deadline yang diberikan oleh klien, manual book untuk project officer dan kru yang menjalankan event dan checklist kebutuhan event. Komunikasi arus diagonal yang Garry lakukan dengan Account Executive sering kali terjadi bahkan setiap saat melalui tatap langsung di kantor maupun melalui whatsapp group. 
- Project Officer (AS) ke Account Executive (RA)

Membahas mengenai project approval, yaitu pengajuan ide maupun saran untuk klien mengenai event yang akan dijalankan yang mempengaruhi ke budget yang akan dikeluarkan oleh klien. Selain itu, juga membahas mengenai margin perusahaan. Komunikasi arus diagonal yang dilakukan biasanya terjadi satu sampai dua kali seminggu melalui meeting. Tetapi, saat mendekati hari $\mathrm{H}$ event, komunikasi dilakukan setiap hari di hari kerja melalui media komunikasi seperti whatsapp group, email dan telepon.

- Account Executive (RA) ke Head of Project Division (GT) dan Project Officer (AS)

Membahas mengenai checklist event yaitu list kebutuhan event, timeline event (Rundown), dan briefing mengenai project event yaitu membicarakan bagaimana nanti tim project akan mengimplementasikan konsep yang sudah matang dibuat oleh tim kreatif serta memberikan info tentang apa yang klien ingin wujudkan dan ekspektasikan dari event tersebut agar saat tim project merealisasikan konsep tersebut klien puas dan sesuai dengan kemauannya. Komunikasi arus diagonal yang dilakukan sangat sering terjadi, yaitu tiga kali dalam seminggu melalui tatap langsung saat meeting dan setiap hari melalui media komunikasi seperti whatsapp group dan email.

\section{Eksternal}

- Head of Project Division (GT) ke klien

Membahas mengenai persiapan event yaitu apa saja yang klien butuhkan, target event yang sedang dijalankan dan evaluasi mengenai event yang telah dijalani.

\section{- Project Manager (AA) ke klien}

Membahas tentang masalah hasil survey lokasi event.

\section{- Project Officer (AS) ke klien}

Membahas masalah mengenai printing \& design approval yaitu desain untuk banner, backdrop, souvenir event, poster ataupun desain cetak yang akan digunakan untuk mendukung event klien, gimmick yang biasanya berbentuk souvenir maupun material pendukung event dan talent untuk pengisi acara.

- Account Executive (RA) ke klien

Membahas masalah mengenai tim internal dari sisi klien dan approval budget yaitu permintaan maupun penawaran yang diajukan saat pihak EO memberikan saran untuk event yang berdampak pada budget yang dikeluarkan oleh klien.

\section{Hambatan Komunikasi Organisasi}

\section{Arus Vertikal (Atas)}

1. Rintangan fisik atau organik berupa jauhnya jarak antara satu sama lain. Contoh : Saat rekan kerja sedang diluar kota untuk menjalankan event lain.

2. Gangguan psikologi, yaitu ego dari masing-masing individu terkadang masih sulit untuk di tahan. Contoh : Ketika pendapat yang dianggap benar tetapi dianggap salah oleh rekan, begitupun sebaliknya.

\section{Arus Vertikal (Bawah)}

1. Faktor rintangan kerangka berpikir berupa perbedaan pendapat atau persepsi. Contoh : Perbedaan pendapat dan pengetahuan terkait kebutuhan event 
2. Gangguan teknis berupa sulitnya rekan kerja untuk dihubungi. Contoh : Rekan kerja sulit dihubungi karena masih menjalankan pekerjaan yang lain.

\section{Arus Horizontal}

1. Gangguan psikologi berupa kurangnya fokus dalam pekerjaan dan saling lupa untuk memberi kabar mengenai update dari klien. Contoh : Lupa memberi kabar mengenai update dari klien karena banyaknya pekerjaan yang dikerjaan saat itu.

2. Gangguan teknis seperti kurangnya komunikasi. Contoh : Kurang komunikasi untuk membicarakan dealing project event.

\section{Arus Diagonal}

1. Gangguan teknis berupa kurangnya waktu untuk bertemu dan melakukan komunikasi. Contoh : Sulit bertemu untuk diskusi karena waktu yang minim, keadaan sedang hectic dan adanya pekerjaan yang lain saat weekend.

\section{Arus Eksternal}

1. Gangguan semantik berupa kesalahpahaman yang disebabkan oleh kata-kata atau bahasa yang digunakan dalam media komunikasi. Contoh : Komunikasi yang dilakukan lewat whatsapp atau email tidak memberikan hasil yang baik karena adanya kesalahpahaman akan bahasa yang digunakan serta perbedaan persepsi yang timbul karena pengertian yang salah saat berkomunikasi di whatsapp.

2. Gangguan psikologi yaitu lupa. Contoh : Lupa dengan hal yang klien minta sehingga kehendak klien tidak terpenuhi.

\section{Pendapat Event Organizer Expert}

Berdasarkan hasil analisis diatas, komunikasi yang dilakukan antara tim project dengan account executive menurut Shelly ialah penting guna melancarkan prosesnya event. Jika komunikasi tidak berjalan dengan baik, maka tim internal EO tidak akan mengetahui betul apa yang diinginkan dan diharapkan klien pada eventnya. Komunikasi yang dilakukan tim internal EO dengan klien pun Shelly anggap penting untuk memuaskan klien dengan pelayanan jasa yang diberikan EO. Tanpa adanya komunikasi yang baik, tim EO tidak akan bisa tahu betul mengenai perubahan-perubahan yang mungkin terjadi saat event berlangsung. Berbicara soal perubahan, hal tersebut harus diketahui oleh klien dan klien berhak mendapatkan informasi mengenai perubahan dan kendala yang terjadi saat event berlangsung. Maka dari itu, komunikasi dinilai sangat penting sekali untuk dijaga.

Menurut Shelly, proses arus komunikasi yang dilakukan tim project dan account executive dalam menangani event dari klien sudah benar karena pada dasarnya proses arus komunikasi yang harus dilakukan tim EO untuk menangani klien adalah seperti yang dilakukan project team dan account executive di PT. Talenta Wirama Berkat. Shelly menambahkan bahwa manfaat dari kelancaran arus komunikasi tersebut adalah event akan menjadi sukses. Shelly menilai bahwa proses komunikasi tim project maupun account executive di PT. Talenta Wirama Berkat dalam menangani kliennya sudah efektif karena mereka telah mengikuti flow event yang benar sehingga apa yang tim project kerjakan di lapangan pun telah sesuai dengan flow yang ada.

Disamping itu, Shelly juga memberikan beberapa saran untuk tim project dan account executive agar hambatan komunikasi yang sering mereka temui dapat diminimalisir yaitu berupa saran untuk lebih sering mengadakan briefing jika memang kendala yang sering ditemukan berupa sulitnya bertemu dengan satu sama lain dan menggunakan media komunikasi sebaik mungkin agar 
komunikasi tidak terputus sehingga data dan semua permasalahan yang ada di lapangan dapat dikomunikasikan sesegera mungkin.

\section{KESIMPULAN}

Berdasarkan hasil penelitian yang didapat oleh peneliti mengenai komunikasi organisasi antara Event Project Team dan Account Executive di Event Organizer PT. Talenta Wirama Berkat serta pembahasan di atas, maka dapat disimpulkan sebagai berikut :

1. Dari temuan penelitian dan pembahasan dapat disimpulkan bahwa bentuk komunikasi organisasi yang dilakukan oleh project team dan account executive di event organizer PT. Talenta Wirama Berkat dibagi menjadi dua dimensi yaitu internal dan eksternal, dimana dalam dimensi internal dibagi lagi menjadi empat arus komunikasi yaitu komunikasi arus atas, komunikasi arus bawah, komunikasi horizontal, dan komunikasi diagonal. Komunikasi eksternal yang dilakukan oleh project team dan account executive merupakan komunikasi yang mereka lakukan dengan kliennya, sedangkan komunikasi internal yang dilakukan terjadi saat account executive memberikan brief mengenai konsep kepada tim kreatif dan tim project. Dalam komunikasi internal, terdapat empat arus komunikasi yang terjadi, yaitu arus horizontal yang terjadi saat account executive berkomunikasi dengan project manager dan tim kreatif, komunikasi vertikal yang terbagi menjadi dua arus yaitu arus bawah yang terjadi saat head of project division berkomunikasi dengan project officer dan project manager ataupun project manager ke project officer, lalu arus atas yang terjadi saat project manager dan project officer berkomunikasi dengan atasannya, serta komunikasi diagonal yang terjadi saat account executive berkomunikasi dengan head of project division dan project officer.

2. Dari temuan penelitian dan pembahasan dapat disimpulkan bahwa hambatan komunikasi dalam proses komunikasi yang dilakukan oleh project team dan account executive di event organizer PT. Talenta Wirama Berkat masih banyak terjadi. Hambatan yang terjadi pada proses komunikasi organisasi di PT. Talenta Wirama Berkat adalah gangguan teknis berupa minimnya waktu untuk berkomunikasi yang disebabkan oleh kuantitas pekerjaan yang banyak, gangguan semantik berupa kesalahpahaman yang disebabkan oleh kata-kata atau bahasa yang digunakan dalam media komunikasi seperti bahasa yang digunakan dalam media komunikasi seperti telepon, email dan whatsapp group, gangguan psikologi berupa kurangnya fokus pada pekerjaan dan lupa akan tugas yang diberikan klien yang disebabkan oleh banyaknya event yang dipegang sehingga overload, rintangan fisik berupa jauhnya jarak antara satu sama lain dan rintangan kerangka berpikir berupa perbedaan pendapat dan persepsi. Hambatan yang terjadi dapat memberikan dampak dan kendala yang mempengaruhi hasil kerja yaitu hasil yang berikan tidak sesuai dengan tujuan dan ekspektasi. Walau ada hambatan, Event Project Team dan Account Executive di PT. Talenta Wirama Berkat telah mendapatkan beberapa solusi untuk menyikapi hambatan tersebut seperti contohnya mengadakan meeting saat komunikasi mulai terhambat dan berusaha untuk menyatukan kembali permasalahan-permasalahan yang ada untuk dirundingkan bersama melalui meeting serta menggunakan media komunikasi yang ada seperti telepon untuk berkomunikasi jika jarak mereka saling berjauhan. 


\section{SARAN}

Berdasarkan penelitian yang sudah dilakukan, terdapat beberapa saran untuk PT. Talenta Wirama Berkat, Event Organizer lainnya dan peneliti lain.

1. Untuk PT. Talenta Wirama Berkat dan Event Organizer lainnya, disarankan untuk mengatur ulang waktu untuk berkomunikasi saat komunikasi mulai terhambat dengan cara mengadakan meeting berkala maupun training dan berusaha untuk menyatukan kembali permasalahanpermasalahan yang ada untuk dirundingkan bersama melalui meeting serta menggunakan media komunikasi yang ada seperti telepon untuk berkomunikasi jika jarak mereka saling berjauhan sehingga dapat mengurangi kemungkinan hambatan komunikasi dapat terjadi.

2. Untuk peneliti selanjutnya, saran dari penelitian ini adalah apabila akan diadakan penelitian lebih lanjut terhadap objek penelitian atau pokok permasalahan yang sama, disarankan untuk tidak hanya meneliti komunikasi organisasi pada Event Project Team dan Account Executive tetapi juga bagaimana strategi komunikasi yang dilakukan Event Project Team dan Account Executive agar komunikasi yang dilakukan menjadi lebih efektif dan mengurangi hambatan yang mungkin bisa terjadi. Diharapkan penelitian ini dapat dijadikan rujukan bagi peneliti lain yang ingin melakukan penelitian lebih lanjut mengenai komunikasi organisasi tetapi dari aspek yang berbeda. Hasil penelitian ini diharapkan bisa dibawa ke dalam proses belajar di kelas guna menambah wawasan mahasiswa mengenai komunikasi organisasi.

\section{DAFTAR PUSTAKA}

Cangara, H. (2016). Pengantar Ilmu Komunikasi (Edisi 2, Cetakan ke-17). Jakarta, Indonesia: PT RajaGrafindo Persada.

Effendy, O. U. (2011). Ilmu Komunikasi : Teori dan Praktek. (Cetakan ke-23). Bandung, Indonesia: PT Remaja Rosdakarya.

Liliweri, A. (2014). Sosiologi \& Komunikasi Organisasi. Jakarta, Indonesia: PT Bumi Aksara.

Mulyana, D. (2013). Ilmu Komunikasi : Suatu Pengantar. Bandung, Indonesia: PT Remaja Rosdakarya.

Natoradjo, S. (2011). Dasar-Dasar Event Management. Jakarta, Indonesia: Gramedia Pustaka Utama. Noor, A. (2017). Manajemen Event. (Edisi Revisi, Cetakan ke-3). Bandung, Indonesia: Alfabeta.

Pace, R. W., \& Faules, D. F. (2013). Komunikasi Organisasi (Cetakan ke-8). (D. Mulyana, Editor). Bandung, Indonesia: PT Remaja Rosdakarya.

Suseno, I. K. (2005). Cara Pinter Jadi Event Organizer. Yogyakarta, Indonesia: Galang Press. Syaikhon, A. (2013, Desember 28). Sejarah Event Organizer di Indonesia. Diperoleh 08 November 2017 dari: http://www.neraca.co.id/article/36565/sejarah-event-organizer-di-indonesia

Twisbless. (n.d.). Homepage. Diperoleh 08 November 2017 dari http://www.twisbless.com/ 